\title{
Editorial
}

This issue of CCT marks the transition to a new stage in the evolution of the journal. The recent changes on Editor and Editorial Committee nurtured a process of strategic reflection, which conduct to the assumption of some adjustments in the organization and display of the journal which will be felt through the next issues, though drawing upon the continuity of the main structural guidelines of this academic publishing project.

A first word should be addressed to the previous Editor and Editorial Team. I would like to express our gratitude to Walter Rodrigues and to his team for all the work conducted during the most recent years on this journal, particularly for the way they managed to deal with the process of transition to an online publication and to adapt it in order to cope with the hard times of deep change that are felt in contemporary academic publishing industry and university life.

Our aim is to keep on with this effort of adjustment to the "zeitgeist" of our times, continuing with the processes of internationalization of the journal and indexing at the main international bibliographic databases, but, on the other hand, keeping and recovering the characteristics that made the identity and specificity of this academic journal, linked to an applied and practice-oriented approach to urban studies and planning, based on a diversity of disciplinary, conceptual and methodological perspectives. It is in the crossing of those two aspects that we believe that our common effort to improve quality must be pursued and the interest of people really concerned with urban studies can be captivated.

A second note is to acknowledge our renewed editorial board, now more open to outside of DINÂMIA'CETIUL, and as always committed with a real multidisciplinary and, whenever possible, transdisciplinary approach to cities' phenomena and with and applied and practice oriented perspective on urban contemporary problematics and challenges.

In this context, this number sets the transition to the use of a standard structure that we intend to apply in the following issues. A thematic dossier, structured around a specific urban problem or challenge, will be developed in each journal issue. With this, we recover an ancient tradition of the journal, and one of its strongest distinctive marks. In each number, an invited or proposed editor will be responsible for the organization of a thematic and coherent set of articles which (even in cases in which they result for specific events, projects or networks) is always subject to an open call, a selection process, and a solid double blind refereeing process. In parallel to each of these thematic dossiers, each issue of the journal will continue to include other double-blind refereed articles, for which submission opportunity is permanently opened, as well as other sections, including studies, projects or book recensions.

The theme of this issue's dossier, centred on the relation between aging and living spaces, crossing perspectives on social urban impacts of ageing dynamics, is particularly interesting for restarting this thematic organization, considering the symbolic and effective importance and challenges this problematics brings to contemporary cities. It is a subject with undeniable relevance, which does not need specific additional presentation, being the context and motivations for this choice presented by the brief introductory text to the dossier "Envelhecimento e espaços de vida: olhares cruzados", written by its coordinators (Filomena Gerardo and Jean-Philippe ViriotDurandall). Besides the great opportunity of the subject, I would just like to highlight the diversity of empirical contexts and problems addressed (and the variety of implication of ageing processes for urban systems), in line with the work of the REIACTIS network, driving us away from an exclusively Eurocentric aging perspective.

Marion Scheider and Thibauld Moulaert introduce the issue of participatory democracy, in their article « La Participation citoyenne à l'épreuve du vieillissement territorial. Quatre études de cas de modèles d'intégration 
citoyenne des aînés dans le Grand-Est français », sheding light on how seniors are part of the definition of their own "living neighbourhoods", drawing upon the analysis of four case studies of older citizen integration in eastern France. George Rouamba, in "Nous étions en ville, nous sommes maintenant en brousse!: l'expérience du déguerpissement d'une femme âgée à Ouagadougou (Burkina Faso)", brings us the discussion of the relation between involuntary intra-urban mobility and identity reconstruction, analysing the experience of eviction through the case of an elderly woman in the context of change of an African metropolis. Finally, Cécile Rosenfelder, in "Les alternatives aux équipements gérontologiques traditionnels, des laboratoires d'expérimentations à l'épreuve des territoires » discusses the new habitats for elderly that are emerging in Europe in the context of ageing population, in order to respond to the shortcomings of the traditional gerontological facilities.

Related with this thematic line, but external to the article section, is also the study "Bonjour Voisin: Participation sociale au sein d'un espace intergénérationnel sur la commune de Saint Apollinaire en France", by Pierre Henri Daure, which describes an inter-institutional project promoting social participation and inter-gerational articulation at a French local community.

Outside the thematic dossier, 3 articles are included on this issue. The first one, by Vera Borges and Ivan Faria, "Jovens, formação e mercados artísticos: estudos no Brasil e em Portugal" leads us to the analysis of the insertion of young people in artistic markets and its relation with training, through a comparative perspective between two studies, in Brazil (Salvador) and Portugal, and evidencing some of the formal and informal mechanisms which are determinant in the structuring of urban artistic communities and labour markets.

The paper "Água corrente (não) mata gente", co-authored by Teresa Marat-Mendes, Joana Mourão, Patrícia Bento d'Almeida, and Samuel Niza, drawing upon a research project on the urban metabolism of Lisbon Metropolitan Area, through the analysis of the uses of water and soil in 1940, characterizes the water supply conditions as well as its implications in terms of sanitation and health, crops and food practices.

Finally, the article by Silvana Bagno and Sérgio Pereira Silva, taking us back to Brazilian urban reality, "Fala Fallet: as memórias de um grupo de idosos de uma favela em Santa Teresa, Rio de Janeiro", brings us again also the aged people, but under another perspective, seeing the evolution of a "Favela" through their narratives and their identity changes.

At the end of this issue, the recension, brought by Rosana Aparecida Martins, on the book "Perseguindo um sonho: A história da fundação da primeira agência de notícias de favelas do mundo”, by André Fernandes, founder of ANF (Agência de Notícias das Favelas), makes us aware of a publication that although being eventually less conventional in academic terms, can be interesting to understand and analyse the role of individual initiative and NGO's at urban development and social inclusion processes.

\section{Pedro Costa}

\section{Editor}

